\title{
COMPARATIVE STUDIES FOR GRAIN YIELD, GRAIN QUALITY, COOKING QUALITY AND NUTRITIONAL VALUE TRAITS OF BLACK RICE VARIETY \\ Metwally,T.F. ${ }^{1}$;Howida B.El-Habat ${ }^{1}$;M.M.El-Malky ${ }^{1}$ andA.S. Barakat ${ }^{2}$ Rice Research and Training Center, Field Crops Research Institute, ARC, Egypt \\ Food Technology Research Institute, Giza, Egypt
}

\begin{abstract}
Food industry shift to use modern techniques and non-traditional components in the production of traditional foods for maximizing the nutritional value of these products inductive meet growing consumer appetites for this type of food. Scientists have discovered that biological compounds with antioxidant effects, such as phenolic and polyphenols compounds have a role in the prevention and treatment of the body from heart disease, cancer tumors and some diseases of aging, such as Alzheimer's. The black rice, a variety tinted widespread in the countries of Asia, and newly cultivated in Egypt, a distinct source of these compounds vital antioxidant. This research aims to field and technological evaluation of black rice variety which newly transferred to Egypt, and the production of sponge cake with a high content of antioxidants using rice flour black.

Field experiments were conducted for four successive rice growing seasons ( 2010, 2011, 2012 and 2013) at the experiential Farm of Rice Research and Training Center (RRTC), Sakha, Kafer El-Sheikh, to study agronomic characters as well as grain quality characters of black rice variety as compared to different rice varieties (Egyptian Yasmine and Pusa Basmati 1 as aromatic varieties and Sakha105 as a high yielding variety). Laboratory studies were carried out at RRTC and at Food Technology Research Institute, Giza, Egypt to evaluate quality of black rice flour.

Concerning agronomic and grain quality characters, black rice variety gave the highest values of grain width $\mathrm{mm}$, head rice $\%$, elongation $\%$ and protein content $\%$. On the other hand, black rice variety recorded the lowest values of plant height $(\mathrm{cm})$, heading date (days), panicle length $(\mathrm{cm})$, no. of panicles hill ${ }^{-1}$, panicle weight $(\mathrm{g})$, no. of filled grains panicles ${ }^{-1}$, grain yield $\mathrm{t} \mathrm{ha}^{-1}$ and grain length $\mathrm{mm}$. The results showed also that black rice flour had higher content of protein, phosphorus, iron, total dietary fiber, ash and ether extract than wheat flour (72\% extraction). Black rice flour was superior as compared to wheat flour in terms of antioxidant content. Replacement of $6 \%$ black rice flour with wheat flour increases each of resistance of extension (B.U.), extensibility $(\mathrm{mm})$, proportional number and energy value $\left(\mathrm{cm}^{2}\right)$ of cake dough. It also increases protein content (\%), total dietary fiber content $(\%)$ and ash content (\%) of cake.
\end{abstract}

This study can guide in the selection and production of rice varieties with enhanced nutritional qualities, suggesting the use of black rice variety in food industry. Keywords: Black rice, agronomic studies, grain quality characters, black rice flour, antioxidant

\section{INTRODUCTION}

Rice is an umbrella term for aquatic grasses in the genus Oryza. Two species of the plant are cultivated as a primary cereal crop all over the world. Asia, Africa, Europe, and the United States all have sizable rice plantations, and rice forms a crucial part of dietary nutrition for many people globally. 
Most consumers are familiar with the concept of long and short grain rice, as well as white and brown rice. In some areas, limited amounts of aromatic rice are available, but few consumers are aware of how many varieties of it there are, along with their myriad uses.

Special rice i.e. aromatic and black rice is important food in the most countries especially in South Asian and other countries. Black rice is currently one for health, which has very reach by a good source of antioxidants. Antioxidants is a substance known for helping individuals flush out body wastes on a regular basis. Different studies by Choi et al. (1994) showed that black rice contains a large amount of anthocyanins, an ingredient that is capable of lowering the risk of heart attack. It does this by preventing the buildup of plaques in the arteries which is the most common reason for heart attacks occur. Even better, it was revealed that anthocyanins is more capable of controlling cholesterol levels than any other food supplement available today. Black rice is also being looked at as possible prevention from serious illnesses. Some of the diseases it can prevent includes include Alzheimer's, diabetes and even cancer.

The food industry is being challenged to redesign traditional foods for optimal nutritional value, in response to some population sectors with particular nutritional necessities (Ronda et al., 2005). Research on the industrial uses of the bioactive compounds from diverse crops has increased extensively. Phenolics are antioxidants, and there is a general belief that the phenolics present in plant food contribute to prevent the oxidative damage that is implicated in a range of diseases, including cancer, cardiovascular diseases and aging (Lin and Weng, 2006). Polyphenols are poorly absorbed and are extensively metabolized in the intestine, liver and possibly brain tissue (Aura, 2008 and Ghosh and Sheepens, 2009). Thus, the modest levels of polyphenols in the blood or brain are unlikely to be high enough to neutralize free radicals chemically, but rather, they may stimulate intracellular signaling pathways leading to vascular protection aside from their direct chemical antioxidative properties (Virgili and Marino, 2008 and Ghosh and Sheepens 2009,).

Accordingly, Schewe et al. (2008) hypothesized that dietary flavonoids, such as anthocyanins, may act as antioxidants in vivo in a more broad sense by interfering with prooxidant processes or by inhibition of prooxidant enzymes. As an alternative mechanism for their health effects, it has been suggested that flavonoids regularly introduced with the diet can act as mild prooxidants and stimulate the endogenous antioxidant defenses, which prevents disease development or reduces the impact of oxidative stress when disease occurs (Moskaug et al., 2005). Many studies have been devoted to genetic engineering of dietary plant materials with increased flavonoid content (Tian et al., 2008). Specifically, a transgenic rice that accumulates both proanthocyanidins and anthocyanins, leading to an increased antioxidant (Finocchiaro et al., 2010). Rice (Oryza sativa L.) is a major cereal crop in the developing world. It is consumed as a staple food by over one-half of the world's population with approximately $95 \%$ of production in Asia (Bhattacharjee, et al., 2002). 
Although, widely consumed as white rice, there are many special cultivars of rice that contain colour pigments, such as black rice, red rice and brown rice. Their name refer to the kernel colour (black, red or purple) which is formed by deposits of anthocyanins in different layers of the pericarp, seed coat and aleurone (Chaudhary, 2003). Rice with a colored pericarp has long been consumed in Japan and China and is considered to be a healthy food. With growing concerns regarding national health and expanding markets of functional products worldwide, some specialty rice cultivars, including black rice and red rice are being developed (Kong and Lee, 2010). Black rice has a number of nutritional advantages over common rice, such as a higher content of protein, vitamins and minerals (Suzuki et al., 2004). Black rice (Oryza sativa $L$. indica), a special cultivar of rice which contains a much higher content of anthocyanins in the aleurone layer than white rice, has been regarded as a food and widely consumed as a health-promoting food in China and other Eastern Asia countries for thousands of years (Wang et al., 2007). The healthy properties of pigmented rice were reported to have the capability of preventing atherosclerosis in mouse model and human study (Lu et al., 2008). These results may in part be attributable to the presence of natural antioxidants (Oki et al., 2002). Xia et al. (2006) reported that chronic diet intake of anthocyanin-rich extract from black rice improved the lipid profile by decreasing serum triglyceride, total cholesterol, and non-HDL cholesterol and may enhance plaque stabilization in old Apo E-deficient mice. The underlying mechanism is related mainly to inhibiting proinflammatory factors and improving the serum lipid profile. Moreover, pigmented rice was reported to have a greater antioxidant capacity than white rice (Choi et al., 2007). Wang et al., (2007) concluded that black rice pigment fraction can reduce some cardiovascular risk factors in patients with coronary heart disease. Those positive effects of black rice pigment fraction may be attributed to the antioxidant and anti-inflammatory activities of anthocyanins contained in black rice pigment fraction. These observations suggest that black rice pigment fraction may serve as an important diet supplement for those individuals with coronary heart disease. Black rice is an especially economically important rice species and derives its name from its rich natural anthocyanin compounds, such as cyanidin 3-glucoside and peonidin 3glucoside, which possess anti-oxidative and anti-inflammatory activities ( $\mathrm{Hu}$ et al., 2003).

Previous investigations have shown that dietary supplementation of black rice pigment significantly inhibits atherosclerotic plaque formation in rabbits (Ling et al., 2002). In addition, black rice contains many beneficial components, including polyphenolics, flavonoids, vitamin E, phytic acid, and c-oryzanol. These antioxidant compounds eliminate reactive oxygen species such as lipid peroxide and superoxide anion radicals and lower cholesterol content (Ichikawa et al., 2001 and Nam et al., 2008). Chronic diet intake of anthocyanin-rich extract from black rice ameliorated the glucose intolerance and hyperlipidemia (Guo et al., 2007). The polyphenolic levels of black rice bran fractions were much higher than those reported in wheat bran (Zhou et al., 2004). 
The main objectives of this study were to: 1) evaluate black rice variety in compare with other different rice verities, 2) evaluate black rice flour in compare with wheat flour and 3) produce sponge cakes with high content of antioxidants using black rice flour.

\section{MATERIALS AND METHODS}

This study was done at Rice Research and Training Center (RRTC), Sakha, Kafer El-Sheikh, and at Food Technology Research Institute, Giza, Egypt. Four rice varieties namely; Black rice, Egyptian Yasmine, Pusa Basmati 1 and Sakha 105 were planted at the experimental farm of RRTC during the rice growing seasons; 2010, 2011, 2012 and 2013. Randomize complete block design with four replications was used.

Table 1: Parentage, type and origin of rice genotypes.

\begin{tabular}{|l|c|c|c|c|}
\hline No & Genotypes & Parentage & Type & Origin \\
\hline 1 & Black rice & Jingu 96 & Japonica & China \\
\hline 2 & E. Yasmine & IR841-67 & Indica & Egypt \\
\hline 3 & Pusa Basmati 1 & Pusa 150/ Karnal local & Indica & India \\
\hline 4 & Sakha105 & GZ5581/ GZ4316 & Japonica & Egypt \\
\hline
\end{tabular}

The seed rate of $96 \mathrm{~kg}$ seed $\mathrm{ha}^{-1}$ for each genotype was used. Clean seeds with at least $90 \%$ germination were soaked in water for 24 hours and incubated for 48 hours. Pre-germinated seeds were sown on first week of May in each season. Seedling at 30 days old (2-3 seedling hill $\left.{ }^{-1}\right)$ were transplanted at $20 \times 20 \mathrm{~cm}$ distance between hills and rows. The plot size measured $4 \times 3 \mathrm{~m}$. The preceding crop was barley. Nitrogen in the form of urea $(46.5 \% \mathrm{~N})$ was added to plots according to the recommendation $(165 \mathrm{~kg}$ $\mathrm{N}$ ha ${ }^{-1}$ ) in two splits application, i.e. one third as basal and incorporated into the soil immediately before flooding, followed by the two thirds after 30 from the first dose. Phosphorus at the rate of $48 \mathrm{~kg} \mathrm{P}_{2} \mathrm{O}_{5} \mathrm{ha}^{-1}$ was applied as basal application during soil preparation. After transplanting, $3 \mathrm{~cm}$ water depth was maintained in the experimental plots. The cultural practices were done as per need of the crop. Insects, diseases, and weeds were intensively controlled to avoid any yield loss. Ten days before harvest, the plots were drained to facilitate harvesting.

Rice plants were harvested when the moisture content of the grain was about $18-20 \%$. Guarded ten square meters from the center of each plot were manually harvested, then gathered in bundles and left in the field for three days to dry. The air-dried bundles were weighed and the total weight of both grain and straw was recorded. The air dried bundles were mechanically threshed and the moisture content was estimated using portable moisture meter. The weight of grains was adjusted to $14 \%$ moisture content. The weight of grain was transformed as tons per hectare.

The agronomic studied characters were; heading date (days), plant height $(\mathrm{cm})$, number of panicle per hill, panicle length $(\mathrm{cm})$, panicle weight (g), number of filled grain per panicle, 100 grain weight $(\mathrm{g})$, sterility $\%$, grain 
yield $\mathrm{t} \mathrm{ha}{ }^{-1}$, grain width $(\mathrm{mm})$, grain length $(\mathrm{mm})$, grain shape, hulling\%, milling\%, head rice, elongation \%, gelatinization temperature, amylose and protein contents. The collected data for traits were subjected to the analysis of variance according to the procedure outlined by Gomez and Gomez (1984). Differences among genotypes means were compared using the Revised LSD at $5 \%$ levels of significance adopted by Waller and Duncan (1969).

Hulling percentage, milling percentage and broken rice percentage, were the ratio of, respectively, brown rice to rough rice, milled rice to rough rice and broken rice to milled rice on a weight basis. For each plot, the $250 \mathrm{~g}$ of rough rice was de-hulled with a a standard de-husker. Brown rice was weighed and hulling percentage was determined. The $150 \mathrm{~g}$ of brown rice was milled with a milling machine. After milling, rice bran was removed with $1.7 \mathrm{~mm}$ sieve. A cleaned sample of milled rice was weighed and milling percentage was determined. From $100 \mathrm{~g}$ of cleaned milled rice, all head rice were taken and weighed, and broken rice percentage was then calculated.

Samples from milled black rice grain were taken and then placed in bags and oven dry at $70 \mathrm{C}^{\circ}$ for 48 hours. Dried samples were ground to powder (black rice flour). Black rice flour and wheat flour (72\% extraction) digested by the wet oxidation procedures according to Johnson and Ulirch (1959) method. Nitrogen content was determined by the Microkjeldahl method (Jackson $1967)$ then, protein content \% was calculated. Total phosphorus content was determined following the procedures of Watanabe and Olsen (1962). A Perkin-Elemer plasma 400 spectrophotometer was used for analysis of zinc, iron and manganese content.

One gram of each wheat and black rice flour was homogenized with $40 \%$ methanol and stirred on a shaker. The extract was filtered through a nylon filter and the solvent was evaporated under vacuum. The dried residue containing phenolic compounds was dissolved in a solution consisting of methanol: water: acetic acid (40: 59.3: 0.7, v: v: v) and stored in brown vials at $5^{\circ} \mathrm{C}$ for analysis. HPLC analysis is used to detect and determine the phenolic compounds as suggested by Christian (1990). The analysis of phenolic compounds was performed on HPLC model Hp 1050, equipped with UV detector. The separation and determination were performed on C 18 column $(150 \times 4.8 \mathrm{~nm})$. The mobile phase consists of methanol: water: acetic acid (40: 59.3: 0.7, v: v: v). the wave length in the UV detector is $254 \mathrm{~nm}$. The run time is $25 \mathrm{~min}$ with $1 \mathrm{ml} . / \mathrm{min}$. of flow rate.

Cakes formula contain $100 \mathrm{~g}$ wheat flour $(72 \%)$, sugar $80 \mathrm{~g}$, shortening $20 \mathrm{~g}$, egg $80 \mathrm{~g}$, vanilla $1 \mathrm{~g}$ and sodium bicarbonate $3 \mathrm{~g}$, according to (Ronda et al., 2005). Black rice flour was replacement with wheat flour by $6 \%$. Butter, eggs and sucrose were mixed for $15 \mathrm{~min}$ using a kitchen-aid mixer. Then, mixture of flour, baking powder and water were added and mixed. Cake dough was placed into two cakes cups and baked for 20 min at $185^{\circ} \mathrm{C}$ in a convection oven. Cakes were kept at room temperature for 30 $\min$.

Farinograph test was carried out according to the method described in the (A. A. C. C., 2002) using Farinograph set (Brabender Farinograph Germany HZ 50 type 877563) to determine the percent of water absorption of 
dough (WA), arrival time of dough (A), dough development time (B), dough stability time (C) and weakening of dough (D). Extensograph test was carried out according to the method described in the (A. A. C. C., 2002) using an extensograph set (Brabender Extensograph Germany HZ 50, type 4821384) to measure dough resistance to extension $(R)$, extensibility $(E)$, proportional number $(\mathrm{R} / \mathrm{E})$ and dough energy value.

Moisture, ash, total dietary fiber, lipids and protein were determined according to the methods recommended by the A. O. A. C. (1995). Total carbohydrates were calculated by difference according to the following equation: Total carbohydrates $=100-(\%$ crude protein $+\%$ crude fat $+\%$ ash). Total calories were calculated using the equation mentioned by $\mathrm{FAO} /$ WHO (1974). Where, energy (calories) $=4$ (carbohydrate + protein) +9 (fat).

\section{RESULTS AND DISCUSSION}

\section{A. Agronomic and yield characters:}

Data in Table 2 indicated that days required to flowering varied significant among the studied varieties. Egyptian Yasmine needs more days to flower as compared with the other varieties while, Black rice required shorter duration to flowering. Karim et al. (2007) studied 41 aromatic rice genotypes for variability and genetic parameter analysis and found highly significant mean sum of square due to genotypes for days to maturity. $\mathrm{He}$ reported that variation for days to maturity was attributed by genetic constituent rather than environment. Short duration lines can a good source for breeder to use as parents. Data in Table 2 showed also that the tallest plants were observed in Pusa Basmati 1 followed by Sakha105 which was very similar to Black rice while Egyptian Yasmine recorded the shortest plants in the first season. The shorter plant height in Egyptian Yasmine was due to shorter internode length. Taller plants produced longest internode than shorter ones. Plant height is mostly governed by the genetic makeup of the cultivar, but the environmental factors also influence it. These results are in agreement with data presented by Mohammad et al. (2002) and Ashrafuzzaman et al. (2009). There were significant differences amongst varieties in number of total panicles per hill (Table 3). The highest values of number of panicles per hill were recoded by Egyptian Yasmine and the lowest values recorded by Black rice.

Table 2: Heading date (days), plant height (cm), and number of panicles hill $^{-1}$ of different rice varieties during 2010, 2011, 2012 and 2013 seasons.

\begin{tabular}{|l|c|c|c|c|c|c|c|c|c|c|c|c|}
\hline \multirow{2}{*}{ Rice varieties } & \multicolumn{3}{|c|}{ Heading date (days) } & \multicolumn{3}{c|}{ Plant height (cm) } & \multicolumn{3}{c|}{ No. of panicles hill $^{-1}$} \\
\cline { 2 - 13 } & $\mathbf{2 0 1 0}$ & $\mathbf{2 0 1 1}$ & $\mathbf{2 0 1 2}$ & $\mathbf{2 0 1 3}$ & $\mathbf{2 0 1 0}$ & $\mathbf{2 0 1 1}$ & $\mathbf{2 0 1 2}$ & $\mathbf{2 0 1 3}$ & $\mathbf{2 0 1 0}$ & $\mathbf{2 0 1 1}$ & $\mathbf{2 0 1 2}$ & $\mathbf{2 0 1 3}$ \\
\hline Black rice & 91.3 & 96.3 & 91.0 & 86.3 & 110.3 & 112.7 & 114.0 & 109.7 & 14.0 & 11.3 & 16.0 & 13.3 \\
E. Yasmine & 107.0 & 114.0 & 115.0 & 111.7 & 108.7 & 113.3 & 125.7 & 115.7 & 21.3 & 18.7 & 20.3 & 20.1 \\
P. Basmati1 & 102.0 & 105.7 & 106.0 & 104.3 & 152.3 & 135.0 & 137.0 & 141.3 & 17.7 & 17.3 & 16.7 & 17.2 \\
Sakha105 & 96.0 & 94.3 & 94.7 & 94.3 & 111.7 & 112.7 & 111.3 & 111.7 & 18.7 & 21.0 & 20.3 & 20.0 \\
LSD at 0.05 & 2.58 & 1.79 & 2.88 & 1.15 & 3.48 & 3.25 & 5.02 & 2.23 & 2.6 & 1.8 & 1.2 & 1.4 \\
\hline
\end{tabular}


The longest panicles were produced by the plants of Pusa Basmati 1 on the other hand; Black rice recorded the shortest panicles. The lightest panicle produced by Black rice. The results revealed that Egyptian Yasmine had much higher sterility percentage which might be due to genetic character of Egyptian Yasmine. It was observed that Pusa Basmati 1 plants produced the highest number of filled grains per panicles as compared to the other varieties (Table 3).

Table 3: Panicle length $(\mathrm{cm})$, panicle weight $(\mathrm{g})$ and number of filled grains panicle ${ }^{-1}$ of different rice varieties during 2010, 2011, 2012 and 2013 seasons.

\begin{tabular}{|c|c|c|c|c|c|c|c|c|c|c|c|c|}
\hline \multirow{2}{*}{$\begin{array}{l}\text { Rice } \\
\text { varieties }\end{array}$} & \multicolumn{4}{|c|}{ Panicle length (cm) } & \multicolumn{4}{|c|}{ Panicle weight (g) } & \multicolumn{4}{|c|}{$\begin{array}{l}\text { No. of filled grains } \\
\text { panicles }^{-1}\end{array}$} \\
\hline & 2010 & 2011 & 2012 & 2013 & 2010 & 2011 & 2012 & 2013 & 2010 & 2011 & 2012 & 2013 \\
\hline & 17.00 & 19.67 & 19.00 & 21.67 & 3.40 & 3.77 & & 3.40 & 131.3 & 139.0 & 130.0 & 125.7 \\
\hline & 25.00 & 26.3 & 25.67 & 25. & 6.5 & & & & 168.7 & 152.7 & & \\
\hline 3asmati1 & 32.00 & 31.67 & 33.00 & 32.33 & 6.28 & 5.80 & & 6.20 & 175.3 & 185.0 & 185.0 & 180.0 \\
\hline & 23.67 & 22.67 & 24.00 & 23.50 & 4.55 & 4.8 & & 4.8 & 166.0 & 157.7 & 163.7 & 162.3 \\
\hline LSD at 0.05 & 1.99 & 1.00 & 1.53 & 1.52 & 0.48 & 0.32 & 0.34 & 0.16 & 4.26 & 11.13 & 12.9 & 4.95 \\
\hline
\end{tabular}

Egyptian Yasmine produced the heaviest 100-grain weight and panicle weight while, the lightest 100-grain recorded by Sakha105. Higher sterility of Egyptian Yasmine decreased the grain yield of this variety. Sakha105 had the highest grain yield plant ${ }^{-1}$ followed by Pusa Basmati 1 . Different varieties exhibited significant differences in grain yield (Table 4). Sakha105 produced the maximum grain yield and Black rice produced the lowest. The genotypes, which produced higher number of effective tillers per hill and lower sterility\% also showed higher grain yield.

Table 4: 100-grain weight (g), sterility\% and grain yield plant ${ }^{-1}$ of different rice varieties during 2010, 2011, 2012 and 2013 seasons.

\begin{tabular}{|l|c|c|c|c|c|c|c|c|c|c|c|c|}
\hline Rice & \multicolumn{3}{|c|}{$\mathbf{1 0 0}-$ grain weight $\mathbf{( g )}$} & \multicolumn{4}{c|}{ Sterility \% } & \multicolumn{3}{c|}{ Grain yield t ha $^{-1}$} \\
\cline { 2 - 12 } varieties & $\mathbf{2 0 1 0}$ & $\mathbf{2 0 1 1}$ & $\mathbf{2 0 1 2}$ & $\mathbf{2 0 1 3}$ & $\mathbf{2 0 1 0}$ & $\mathbf{2 0 1 1}$ & $\mathbf{2 0 1 2}$ & $\mathbf{2 0 1 3}$ & $\mathbf{2 0 1 0}$ & $\mathbf{2 0 1 1}$ & $\mathbf{2 0 1 2}$ & $\mathbf{2 0 1 3}$ \\
\hline Black rice & 2.87 & 2.90 & 2.90 & 2.83 & 5.03 & 5.07 & 5.20 & 6.30 & 6.88 & 6.75 & 6.79 & 6.98 \\
E. Yasmine & 3.20 & 3.10 & 2.97 & 3.09 & 20.57 & 18.99 & 21.90 & 20.47 & 8.61 & 8.91 & 8.37 & 8.63 \\
P. Basmati1 & 2.52 & 2.53 & 2.57 & 2.54 & 15.38 & 14.65 & 16.25 & 15.47 & 10.53 & 10.54 & 9.89 & 10.33 \\
Sakha105 & 2.80 & 2.83 & 2.77 & 2.81 & 4.75 & 5.60 & 5.87 & 5.37 & 11.40 & 11.15 & 12.15 & 11.31 \\
LSD at 0.05 & 0.14 & 0.17 & 0.13 & 0.17 & 1.45 & 0.98 & 1.81 & 0.61 & 0.57 & 0.47 & 0.50 & 0.55 \\
\hline
\end{tabular}

\section{B. Grain quality characters:}

Data (Table 5) revealed that the highest grain width was observed in Black rice followed by Sakha105. The lowest grain width was obtained in Pusa Basmati 1. Pusa Basmati 1 had the highest grain length and Black rice had shortest length. Black rice possessed the lowest length grain shape values. The genotype Pusa Basmati 1 possessed the highest grain shape values. Determining the rice grain shape and width are highly essential as both, cooking and eating properties are strongly influenced by these (McKenzie and Ruther, 1983 and Rachel et al. 2013). 
Table 5: Grain width $(\mathrm{mm})$, grain length $(\mathrm{mm})$ and grain shape of different rice varieties in 2010, 2011, 2012 and 2013 seasons.

\begin{tabular}{|l|c|c|c|c|c|c|c|c|c|c|c|c|}
\hline \multirow{2}{*}{ Rice varieties } & \multicolumn{3}{|c|}{ Grain width $\mathbf{~ m m}$} & \multicolumn{3}{c|}{ Grain length $\mathbf{m m}$} & \multicolumn{4}{c|}{ Grain shape } \\
\cline { 2 - 13 } & $\mathbf{2 0 1 0}$ & $\mathbf{2 0 1 1}$ & $\mathbf{2 0 1 2}$ & $\mathbf{2 0 1 3}$ & $\mathbf{2 0 1 0}$ & $\mathbf{2 0 1 1}$ & $\mathbf{2 0 1 2}$ & $\mathbf{2 0 1 3}$ & $\mathbf{2 0 1 0}$ & $\mathbf{2 0 1 1}$ & $\mathbf{2 0 1 2}$ & $\mathbf{2 0 1 3}$ \\
\hline Black rice & 2.90 & 2.97 & 2.93 & 3.22 & 5.55 & 5.43 & 5.70 & 5.79 & 1.85 & 1.83 & 2.04 & 1.87 \\
E. Yasmine & 2.35 & 2.29 & 2.34 & 2.32 & 7.24 & 7.12 & 7.16 & 7.17 & 2.95 & 2.67 & 2.93 & 2.85 \\
P. Basmati1 & 2.01 & 1.97 & 1.98 & 1.98 & 7.63 & 7.35 & 7.28 & 7.42 & 3.48 & 3.36 & 3.32 & 3.38 \\
Sakha105 & 2.60 & 2.73 & 2.63 & 2.65 & 5.79 & 5.91 & 5.86 & 5.85 & 2.15 & 2.05 & 2.10 & 2.09 \\
LSD at 0.05 & 0.10 & 0.08 & 0.09 & 0.06 & 0.19 & 0.08 & 0.18 & 0.16 & 0.07 & 0.58 & 0.11 & 0.26 \\
\hline
\end{tabular}

The hulling percentage for rice varieties ranged from $76.8-82.3$ (Table 6). The highest hulling was noted in variety Sakha105 which was statistically identical with E. Yasmine and lowest in Pusa Basmati 1. Among the varieties studied, the milling \% ranged from 60.2-72.3. The variety Sakha105 recorded the highest milling \% and least was found in Pusa Basmati 1. Rita and Sarawgi (2008) reported that the more than 80 value of hulling percentage is preferred and if the hulling percentage increases the head rice recovery also increased. Among the studied varieties, the head rice\% ranged from $49.3-61.4 \%$. The variety Black rice recorded the highest head rice\% and least was found in Pusa Basmati 1.

Table 6: Hulling\%, milling\%and head rice\% of different rice varieties during 2010, 2011, 2012 and 2013 seasons.

\begin{tabular}{|l|c|c|c|c|c|c|c|c|c|c|c|c|}
\hline \multirow{2}{*}{$\begin{array}{l}\text { Rice } \\
\text { varieties }\end{array}$} & $\mathbf{4 0 1 0}$ & $\mathbf{2 0 1 1}$ & $\mathbf{2 0 1 2}$ & $\mathbf{2 0 1 3}$ & $\mathbf{2 0 1 0}$ & $\mathbf{2 0 1 1}$ & $\mathbf{2 0 1 2}$ & $\mathbf{2 0 1 3}$ & $\mathbf{2 0 1 0}$ & $\mathbf{2 0 1 1}$ & $\mathbf{2 0 1 2}$ & $\mathbf{2 0 1 3}$ \\
\cline { 2 - 12 } \\
\hline Black rice & 78.5 & 77.4 & 78.5 & 81.3 & 69.7 & 67.2 & 67.4 & 70.6 & 61.0 & 60.1 & 60.5 & 61.4 \\
E. Yasmine & 82.0 & 82.2 & 81.6 & 82.3 & 65.3 & 65.2 & 65.2 & 65.2 & 50.8 & 51.3 & 53.3 & 51.8 \\
P. Basmati1 & 77.6 & 77.7 & 76.8 & 77.3 & 60.7 & 60.6 & 59.5 & 60.2 & 49.7 & 49.3 & 51.3 & 49.9 \\
Sakha105 & 82.3 & 81.4 & 82.0 & 81.9 & 72.1 & 72.3 & 71.9 & 72.1 & 59.6 & 60.9 & 61.4 & 60.9 \\
LSD at 0.05 & 2.0 & 1.5 & 1.3 & 1.3 & 1.3 & 1.9 & 1.8 & 0.7 & 0.9 & 2.0 & 2.1 & 1.8 \\
\hline
\end{tabular}

\section{Cooking quality characters:}

Among the rice varieties examined, data in Table 7 showed that Black rice recorded the highest values of elongation \% while Egyptian Yasmine recorded the lowest ones. The gelatinization temperature values ranged from 5.67 to 6.93 . The highest values of gelatinization temperature recorded by Pusa Basmati 1. Amylose content ranged from 17.77-27.20\%. The lowest level of AC was recorded in Sakha105, whereas highest in Pusa Basmati 1.

The protein content in all the varieties studied ranged from 5.5010.53. The highest protein content values were recorded in Black rice. Sakha105 has the lowest content of protein. Rachel et al. (2013) indicated that amylose content can play a significant role in determining the overall cooking, eating and pasting properties of a rice variety. Apart from the amylose content, the cooking quality of rice can also be influenced by components such as: proteins, lipids or amylopectin. They also reported that, a positive correlation was observed wherein, rice varieties which had higher amylose content, required a shorter cooking time. Rachel et al. (2013) indicated that differences in the observed amylose content among different rice varieties can also affect the cooking properties. 
Table 7: Elongation \%, Gelatinization temperature, Amylose content, and Protein content of different rice varieties during 2010, 2011, 2012 and 2013 seasons.

\begin{tabular}{|l|c|c|c|c|c|c|c|c|}
\hline \multirow{2}{*}{ Rice varieties } & \multicolumn{4}{|c|}{ Elongation \% } & \multicolumn{3}{c|}{ Gelatinization temperature } \\
\cline { 2 - 9 } & $\mathbf{2 0 1 0}$ & $\mathbf{2 0 1 1}$ & $\mathbf{2 0 1 2}$ & $\mathbf{2 0 1 3}$ & $\mathbf{2 0 1 0}$ & $\mathbf{2 0 1 1}$ & $\mathbf{2 0 1 2}$ & $\mathbf{2 0 1 3}$ \\
\hline Black rice & 53.47 & 51.93 & 51.07 & 52.18 & 5.88 & 5.67 & 5.90 & 5.67 \\
E. Yasmine & 11.64 & 12.61 & 16.24 & 13.50 & 5.77 & 5.80 & 6.00 & 5.85 \\
P. Basmati1 & 43.49 & 43.22 & 42.66 & 43.10 & 6.93 & 6.75 & 6.90 & 6.86 \\
Sakha105 & 25.19 & 24.91 & 26.65 & 25.57 & 5.87 & 5.80 & 5.76 & 5.81 \\
LSD at 0.05 & 4.01 & 2.30 & 2.35 & 1.83 & 0.48 & 0.60 & 0.37 & 0.60 \\
\hline Rice varieties & \multicolumn{3}{|c|}{ Amylose content \% } & \multicolumn{5}{|c|}{ Protein content \% } \\
\cline { 2 - 9 } & 2010 & 2011 & 2012 & 2013 & 2010 & 2011 & 2012 & 2013 \\
\hline Black rice & 20.70 & 20.53 & 20.13 & 20.03 & 10.53 & 10.43 & 9.63 & 10.53 \\
E. Yasmine & 21.85 & 21.47 & 22.21 & 21.84 & 7.22 & 7.10 & 7.15 & 7.15 \\
P. Basmati1 & 26.10 & 27.20 & 26.77 & 26.67 & 6.75 & 6.50 & 6.25 & 6.50 \\
Sakha105 & 17.77 & 18.25 & 17.83 & 17.97 & 5.50 & 5.74 & 5.57 & 5.60 \\
LSD at 0.05 & 0.49 & 0.72 & 1.24 & 0.57 & 1.04 & 0.76 & 0.92 & 0.86 \\
\hline
\end{tabular}

D. Nutritional value traits:

\section{Chemical composition of flour of wheat and black rice:}

Chemical composition of the wheat and black rice flour are shown in Table 8. Data showed that wheat flour contained $9.9 \%$ protein, $0.20 \% \mathrm{P}$, $0.42 \% \mathrm{~K}, 150 \mathrm{ppm} \mathrm{Fe}, 50 \mathrm{ppm} \mathrm{Zn,} 60 \mathrm{ppm} \mathrm{Mn}, 84.5 \%$ total carbohydrates, $3.4 \%$ total dietary fibers, $0.4 \%$ ash and $1.8 \%$ ether extract. Data showed also that black rice flour contained $10.8 \%$ protein, $0.26 \% \mathrm{P}, 0.35 \% \mathrm{~K}, 170.80 \mathrm{ppm}$ Fe, 35.5 ppm Zn, 53.4 ppm Mn, 79.3\% total carbohydrates, $4.7 \%$ total dietary fibers, $1.9 \%$ ash and $3.3 \%$ ether extract.

Rachel et al. 2013 found that black rice is also known to be a good source of fiber compared to different rice varieties as well as carbohydrate content was high in Black rice (> 70\%) and hence can be considered to be a good source of carbohydrate. They also reported that the ash content was higher in black rice than white rice thus, the amount of ash present in a food sample plays an important role while determining the levels of essential minerals

Table 8: Chemical composition of the wheat and black rice flour (on dry basis):

\begin{tabular}{|l|c|c|c|c|c|c|c|c|c|c|}
\hline Materials & $\begin{array}{c}\text { Protein } \\
(\%)\end{array}$ & $\% \mathbf{P}$ & $\% \mathbf{K}$ & $\begin{array}{c}\mathbf{F e} \\
(\mathbf{p p m})\end{array}$ & $\begin{array}{c}\mathbf{Z n} \\
(\mathbf{p p m})\end{array}$ & $\begin{array}{c}\mathbf{M n} \\
(\mathbf{p p m})\end{array}$ & $\begin{array}{c}\mathbf{T C}^{*} \\
(\%)\end{array}$ & $\begin{array}{c}\text { TD** } \\
(\%)\end{array}$ & $\begin{array}{c}\text { Ash } \\
(\%)\end{array}$ & $\begin{array}{c}\text { Ether } \\
\mathbf{e x t r a c t} \\
(\%)\end{array}$ \\
\hline $\begin{array}{l}\text { Wheat flour } \\
(72 \%)\end{array}$ & 9.9 & 0.20 & 0.42 & 150.0 & 50.00 & 60.00 & 84.5 & 3.4 & 0.4 & 1.8 \\
\hline $\begin{array}{l}\text { Black rice } \\
\text { flour }\end{array}$ & 10.8 & 0.26 & 0.35 & 170.80 & 35.50 & 53.40 & 79.3 & 4.7 & 1.9 & 3.3 \\
\hline
\end{tabular}

${ }^{\star}$ Total carbohydrates. ${ }^{\star \star}$ Total dietary fiber.

\section{Antioxidant content of wheat and black rice flour:}

Phenolic content of wheat and black rice flour are shown in Table 9. Data showed that black rice is an excellent source of phenolic acids. Results in Table 9 obvious also that pyrogalol is the abundant acid in wheat flour $(82 \%)$ and benzoic acid is the abundant acid in black rice. Sompong et al. 
(2011) reported that total phenolic content of black rice ranged from 336 to $665 \mathrm{mg} / 100 \mathrm{~g}$. Sirichet et al. (2010) reported that free radicals cause cellular damage and eventually progress to chronic diseases and phenolic compounds play a crucial role in radicals scavenging. Also, Eun Hee et al. (2007) reported that rice ferulic acid which possesses antioxidant activities, show promising effects as preventive and therapeutic agents. Estimation of ferulic acid and anthocyanins content of black rice was not available because its standards were not available. Anthocyanins content of black rice reach to $256 \mathrm{mg} / 100 \mathrm{~g}$ as estimated by Sompong et al. (2011).

Table 9: Antioxidant content of wheat flour and black rice:

\begin{tabular}{|l|c|c|c|c|c|c|c|c|c|}
\hline \multirow{2}{*}{ Samples } & \multicolumn{8}{|c|}{ 1000g)/Phenolic acids contents (mg } \\
\cline { 2 - 11 } & Galic & P.Coumaric & Vanilic & Catechin & pyrogalol & Chiricin & Salysilic & Benzoic & Caffeic \\
\hline Wheat flour & 28 & 1.2 & 6.6 & 4.0 & 50 & 0.02 & 0.1 & 20 & 1.9 \\
\hline $\begin{array}{l}\text { Black rice } \\
\text { flour }\end{array}$ & 76 & 2.0 & 27.7 & 469 & 232.0 & 2.3 & 14 & 587 & 20 \\
\hline
\end{tabular}

Effect of black rice flour on farinograph and extensograph properties of dough:

Effects of replacement of black rice flour with wheat flour on farinograph properties of dough are shown in Table 10. The results showed that water absorption, arrival time, development time, stability time and degree of weakening of control dough was $54.6 \%, 0.5 \mathrm{~min}$., $1 \mathrm{~min}$., $2.5 \mathrm{~min}$. and 120 B. U., respectively. The results in Table 10 showed also that replacement of black rice flour with $6 \%$ of wheat flour did not affect in water absorption, arrival time, development time and stability time of dough. Degree of weakening decreased from $120 \mathrm{~B}$. U. in control sample to $95 \mathrm{~B}$. U. by replacement of black rice flour with $6 \%$ of wheat flour.

Effects of replacement of black rice flour with wheat flour on extensograph properties of dough are shown in Table 10. The results showed that replacement of black rice flour with wheat flour increased resistance of extension. The results showed also that replacement of black rice flour with $6 \%$ of wheat flour increased extensibility, proportional number and energy of dough.

Table 10: Effect of black rice flour on farinograph and extensograph properties of dough:

\begin{tabular}{|l|c|c|c|c|c|c|c|c|c|}
\hline Dough with & $\begin{array}{c}\text { Water } \\
\text { absorption } \\
(\%)\end{array}$ & $\begin{array}{c}\text { Arrival } \\
\text { time } \\
(\mathrm{min})\end{array}$ & $\begin{array}{c}\text { Development } \\
\text { time } \\
(\mathrm{min})\end{array}$ & $\begin{array}{c}\text { Stability } \\
\text { time } \\
(\mathrm{min})\end{array}$ & $\begin{array}{c}\text { Degree of } \\
\text { weakening } \\
(\mathrm{B} . \mathrm{U})\end{array}$ & $\begin{array}{c}\text { Resistance } \\
\text { of extension } \\
(\text { B.U. })\end{array}$ & $\begin{array}{c}\text { Extensibility } \\
(\mathrm{mm})\end{array}$ & $\begin{array}{c}\text { Proportional } \\
\text { number }\end{array}$ & $\begin{array}{c}\text { Energy } \\
\text { value } \\
\left(\mathrm{cm}^{2}\right)\end{array}$ \\
\hline $\begin{array}{l}\text { Wheat } \\
\text { flour only }\end{array}$ & 54.6 & 0.5 & 1.0 & 2.5 & 120 & 505 & 123 & 4.1 & 92 \\
\hline $\begin{array}{l}\text { Wheat } \\
\text { flour + 6\% } \\
\text { Black rice }\end{array}$ & 54.6 & 0.5 & 1.0 & 2.5 & 95 & 540 & 128 & 4.2 & 108 \\
\hline
\end{tabular}

*: In Brabender units. 


\section{Effect of black rice flour on chemical composition and energy content of cakes:}

Effects of replacement of black rice flour with wheat flour on chemical composition and energy content of cakes are shown in Table 11. The results showed that protein, total dietary fiber, ash and ether extract content of produced cakes slightly increased with using black rice flour comparing with control cake. While total carbohydrates and energy slightly decreased with using black rice flour comparing with control cake.

Table 11: Effect of black rice on chemical composition and energy content of cakes (on dry wet basis).

\begin{tabular}{|l|c|c|c|c|c|c|}
\hline Cakes with & $\begin{array}{c}\text { Protein } \\
(\%)\end{array}$ & $\begin{array}{c}\text { TC*}^{\star} \\
(\%)\end{array}$ & $\begin{array}{c}\text { TD** } \\
(\%)\end{array}$ & $\begin{array}{c}\text { Ash } \\
(\%)\end{array}$ & $\begin{array}{c}\text { Ether } \\
\text { extract } \\
(\%)\end{array}$ & $\begin{array}{c}\text { Energy } \\
\text { (calories) }\end{array}$ \\
\hline $\begin{array}{l}\text { Wheat flour } \\
\text { only }\end{array}$ & 10.2 & 72.6 & 1.4 & 1.3 & 14.5 & 461.5 \\
\hline $\begin{array}{l}\text { Wheat flour + 6\% } \\
\text { Black rice }\end{array}$ & 11.6 & 70.6 & 1.6 & 2.4 & 13.8 & 453.0 \\
\hline
\end{tabular}

${ }^{\star}$ Total carbohydrates. ${ }^{* \star}$ Total dietary fiber.

\section{REFERENCES}

A. A. C. C. (2002). Approved methods of the American Association of Cereal Chemists. Published by the American Association of Cereal Chemists Inc. St. Paul., Minnesota, USA.

A. O. A. C. (1995). Association of Official Analysis Chemists. Arlington, Virginia, USA.

Ashrafuzzaman, M.; Islam M.R.; Ismail, M.R.; Shahidullah, S.M. and Hanafi, M.M. (2009). Evaluation of six aromatic rice varieties for yield and yield contributing characters. Int. J. Agric. Biol., 11: 616-620.

Aura, A. (2008). Microbial metabolism of dietary phenolic compounds in the colon. Phytochemistry Reviews, 7: 407-429.

Bhattacharjee, P.; Singhal, R. and Kulkarni, P. (2002). Basmati rice: A review. International J. of Food Sci. and Technology, 37(1): 1-12.

Chaudhary, R. (2003). Speciality rices of the world: Effect of WTO and IPR on its production trend and marketing. J. of Food, Agriculture and Environment, 1(2): 34-41.

Choi, Y.; Jeong, H. and Lee, J. (2007). Antioxidant activity of methanolic extracts from some grains consumed in Korea. Food Chemistry, 103: $130-138$.

Choi,S.W.; Kang, W.W. and Osawa, T. (1994). Isolation and identification of anthocyanin pigments in black rice. Food and Biotechnology, 3: 131136.

Christian, G. (1990). HPLC Tips and Tricks. Great Britain at the Iden Press, Oxford pp. 608.

Eun Hee, J.; Sung Ran, K.; Inkyeon, H. and Taeyoul, H. (2007). Hypoglycemic effects of phenolic acid fraction of rice bran and ferulic acid mice. J. Agic. and Food Chem., 55: 9800- 9804. 
FAO/ WHO (1974). Handbook on human nutritional requirements. Published by FAO, p.53-63, Rome.

Finocchiaro, F.; Ferrari, B. and Gianinett, A. (2010). A study of biodiversity of flavonoid content in the rice caryopsis evidencing simultaneous accumulation of anthocyanins and proanthocyanidins in a black grained genotype. J. Cereal Sci., 51: 28-34.

Ghosh, D. and Sheepens, A. (2009). Vascular action of polyphenols. Molecular Nutrition and Food Research, 53:322-331.

Gomez, K.A. and Gomez, A.A. (1984). Statistical procedure for agicultural research. $2^{\text {nd }}$ Ed. Johin Wiley Sons. New yourk. USA.

Guo, H.; Ling, W.; Wang, Q.; Liu, C.; Hu, Y.; Xia, M.; Feng, X. and Xia, X. (2007). Effect of anthocyanin-rich extract from black rice (Oryza sativa L. indica) on hyperlipidemia and insulin resistance in fructose-fed rats. Plant Foods for Human Nutrition, 62: 1-6.

Hu, C.; Zawistowski, J.; Ling, W. and Kitt, D. (2003). Black rice (Oryza sativa $\mathrm{L}$. indica) pigmented fraction suppresses both reaction oxygen species and nitric oxide in chemical and biological model systems. J. of Agricultural Food Chemistry, 51: 5271-5277.

Ichikawa, H.; Ichiyanagi, T.; Xu, B.; Yoshii, Y.; Nakajima, M. and Konishi, T. (2001). Antioxidant activity of anthocyanin extract from purple black rice. J. of Medicinal Food, 4(4):211-218.

Jackson, M.L. (1967). Soil Chemical Analysis. Printic Hall of India, New Delhi. 144-197.

Johonson, C.W. and A. Ulrich, (1959). Analytical Methods For Use in Plant Analysis. Calif. Agric. Expt. Station. Bull., 716:32-33.

Karim D. U.; Sarkar M.N.A.; Siddique M. A.; Khaleque Miah and M. Z. Hasnat. (2007). Variability and Genetic Parameter Analysis in Aromatic Rice. Int. J. Sustain. Crop Prod., 2(5):15-18.

Kong, S. and Lee, J. (2010). Antioxidants in milling fractions of black rice cultivars. Food Chemistry, 120: 278-281.

Lin, J. and Weng, M. (2006). Flavonoids as nutraceuticals. In: Grotewold, E. (Ed.), The Sci.of Flavonoids. Springer, New York (USA), pp. 213-238.

Ling, W.; Wang, L. and Ma, J. (2002). Supplementation of the black rice outer layer fraction to rabbits decreases atherosclerotic plaque formation and increases antioxidant status. J. of Nutrition, 132: 20-26.

Lu, Z.; Kou, W.; Du, B.; Wu, Y.; Zhao, S. and Brusco, O. (2008). Effect of Xuezhikang, and extract from red yeast Chinese rice, on coronary events in a Chinese population with previous myocardial infarction. The American J. of Cardiology, 101, 1689-1693.

McKenzie, K. S. and Ruther J. N. (1983). Rice grain shape and rice grain quality. Crop Sci., 23: 306-313.

Mohammad, T.; Deva, W.and Ahmad, Z. (2002). Genetic variability of different plant and yield characters in rice. Sarhad J. Agric., 18: 207210.

Moskaug, J., Carlsen, H.; Myhrstad, M. and Blomhoff, R. (2005). Polyphenols and glutathione synthesis regulation. American J. of Clinical Nutrition, $81: 277-283$. 
Nam, Y.J.; Nam, S. H. and Kang, M. Y. (2008). Cholesterol-lowering efficacy of unrefined bran oil from the pigmented black rice (Oryza sativa L cv. Suwon 415) in hypercholesterolemic rats. Food Sci.and Biotechnology, 17(3): 457-463.

Oki, T.; Masuda, M.; Kobayashi, M.; Nishiba, Y.; Furuta, S. and Suda, I. (2002). Polymeric procyanidins as radical-scavenging components in red-hulled rice. J. Agricultural Food Chemistry, 50: 7524-7529.

Rachel, T.; Wan, N.; Wan. N. and Rajeev, B. (2013). Physiochemical properties, proximate composition, and cooking qualities of locally grown and imported rice varieties marketed in Penang, Malaysia. Inter. Food Res. J., 20(3): 1345-1351.

Rita, B. and Sarawgi, A. K. (2008). Agro-morphological and quality characterization of badshah bhog group from aromatic rice germplasm of Chhattisgarh. Bangladesh J. of Agriculture Research, 33(3):479-492.

Ronda, F., Gomez, M.; Blanco, C. and Caballero, P. (2005). Effects of polyols and nondigestible oligosaccharides on the quality of sugar-free sponge cakes. Food Chemistry, 90: 549-555.

Schewe, T.; Steffen, Y. and Sies, H. (2008). How do dietary flavanols improve vascular function? A position paper. Archives of Biochemistry and Biophysics, 476:102-106.

Sirichet R., Prasit, S., Suda, R., Chaiyavat, C. and Somsak, P. (2010). Phenolic content and antioxidant activities in red unpolished Thai rice prevents oxidative stress in rats. J. Medicinal Plants Research, 4 (9): 796-801.

Sompong, R.; Siebenhandl-Ehn, S.; Linsberger-Martin G. and Berghofer G. (2011). Physicochemical and antioxidative properties of red and black rice varieties from Thailand, China and Sri Lanka. Food Chemistry, 124: 132-140.

Suzuki, M.; Kimura, T.; Yamagishi, K.; Shinmoto, H.; and Yamaki, K. (2004). Comparison of mineral contents in 8 cultivars of pigmented brown rice. Nippon Shokuhin Kagaku Kogaku Kaishi, 51(8): 424-427.

Tian, L.; Pang, Y. and Dixon, R. (2008). Biosynthesis and genetic engineering of proanthocyanidins and (iso)flavonoids. Phytochemistry Reviews 7: 445-465.

Virgili, F. and Marino, M. (2008). Regulation of cellular signals from nutritional molecules: a specific role for phytochemicals, beyond antioxidant activity. Free Radical Biology and Medicine, 45: 1205-1216.

Waller, R.A. and Duncan. D.B. (1969). Base rule comparison symmetric multiple comparison proplem. Amer - stat Assoc. J., 1485-1503.

Wang, Q.; Han, P.; Zhang, M.; Xia, M.; Zhu, H.; Ma, J.; Hou, M.; Tang, Z. and Ling, W. (2007). Supplementation of black rice pigment fraction improves antioxidant and anti-inflammatory status in patients with coronary heart disease. Asia Pac. J. Clin. Nutr., 16 (Suppl., 1): 295301.

Watanabe, F.S. and S. A. Olsen. (1962). Calorimetric determination of phosphorus in water extract. Soil Sci., 93:183-188. 
Xia, X.; Ling, W.; Ma, J.; Xia, M.; Hou, M.; Wang, Q.; Zhu, H. and Tang, Z. (2006). Anthocyanin-Rich Extract from Black Rice Enhances Atherosclerotic Plaque Stabilization in Apolipoprotein E-Deficient Mice. J. Nutr. 136:2220-2225.

Zhou, K.; Su, L., and Yu, L. (2004). Photochemical and antioxidant properties in wheat bran. J. of Agricultural Food Chemistry, 52:6108-6114.

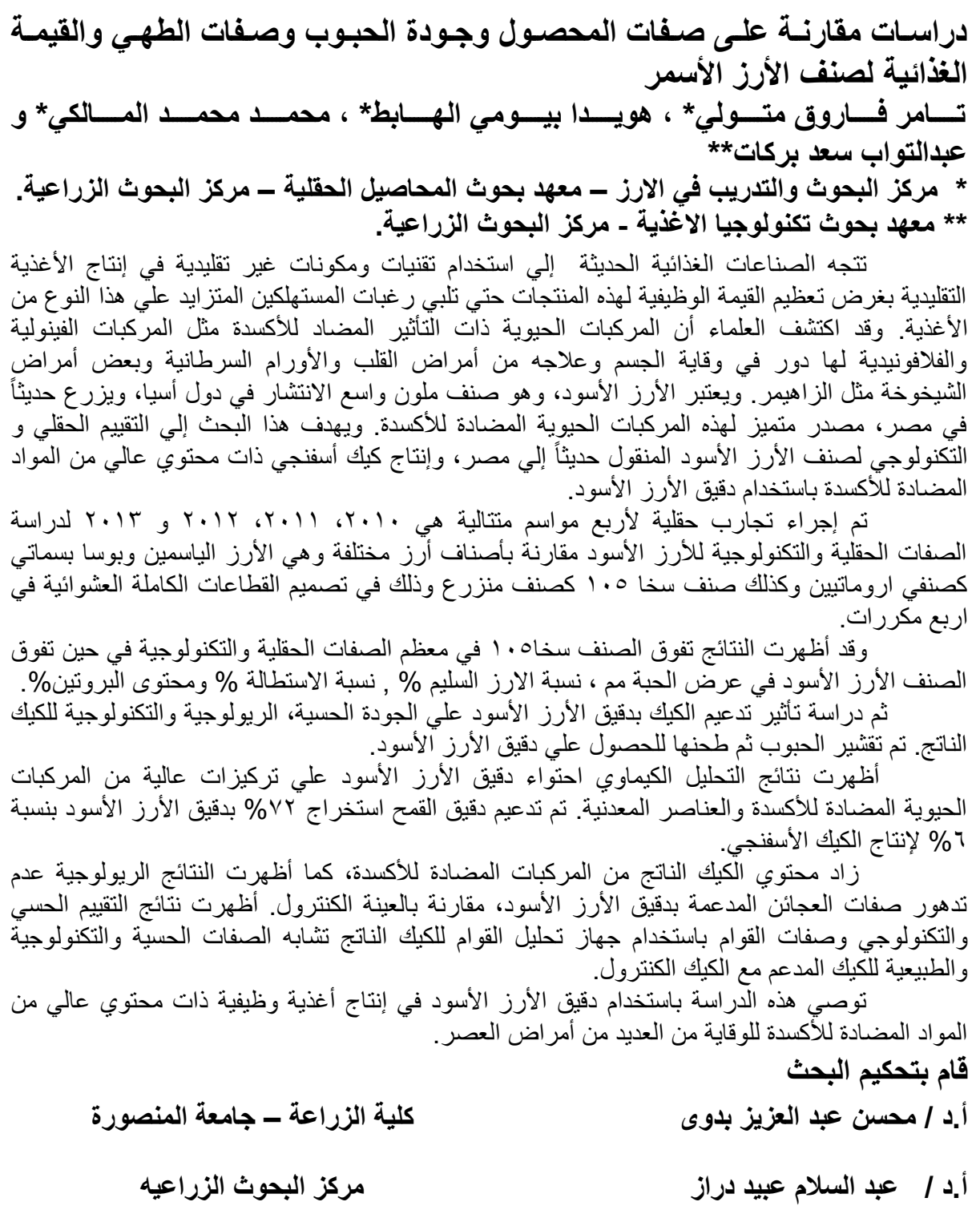


J. Plant Production, Mansoura Univ., Vol. 5 (3), March, 2014 